\title{
Answer to the letter to the editor regarding the article "Informed consent: recommendations for its documentation"
}

Miguel Ángel Celis, Julio Sotelo*, José Halabe, Oscar Arrieta, Rubén Burgos, Carlos Campillo, Manuel De la Llata, Judith Domínguez, Sergio Islas, Luis Jasso-Gutiérrez, Alberto Lifshitz, Mucio Moreno, Ricardo Plancarte, Alejandro Reyes-Sánchez, Guillermo Ruiz-Argüelles, Antonio Soda and Emma Verástegui

Comité de Ética y Transparencia en la Relación Médico-Industria, Academia Nacional de Medicina, Ciudad de México, Mexico

The Committee of Ethics and Transparency in the Physician-Industry Relationship (CETREMI) developed the proposal "Informed consent. Recommendations for its documentation", with the purpose to draw the attention of the medical community about behavior and practices in public and private health institutions, where little space is given to the participation of patients in decision - making. This phenomenon is perceived as a source of conflicts and complaints among users, resulting from poor communication.

As stated in the article, "health personnel must act with ethics and transparency following the principles of beneficence and non-maleficence" when providing information, but should not be above the principle of autonomy in patient decisions. Therefore, the CETREMI recommendations are clear and precise, as a call to reflection and self-criticism that favors better doctor-patient and patient-institution relationships, which will also result in better practices and comprehensive quality of care.

\section{References}

1. Celis MÁ, Halabe J, Arrieta O, Burgos R, Campillo C, De la Llata M, et al. El consentimiento informado: recomendaciones para su documentación. Gac Med Mex. 2018:154:716-718. DOI: 10.24875/GMM.18004339.
Gac Med Mex. 2019;155:202-202

Contents available at PubMed www.gacetamedicademexico.com 